\title{
Artikel
}

\section{De rechtspositie van aangehouden minderjarige verdachten in de eerste fase van het strafrechtelijk onderzoek}

\author{
Mr. drs. M. (Marije) Jeltes*
}

\section{Inleiding}

In deze bijdrage wordt de rechtspositie van angehouden minderjarige verdachten vanaf het moment van aanhouding tot en met de voorgeleiding onderzocht en naast de lat van Europese en internationale kinderrechten gelegd. Welke rechten en plichten hebben minderjarige verdachten in het Nederlandse rechtssysteem tijdens de eerste fase van het strafrechtelijk onderzoek, welke rol hebben Europese regelgeving en internationale kinderrechten in de totstandkoming van deze rechten en plichten gespeeld, en voldoet Nederland aan dit internationale kader van kinderrechten?

\section{Rechten van de aangehouden minderjarige verdachte}

Vanaf het moment dat een minderjarige verdachte wordt aangehouden, maakt hij aanspraak op een aantal rechten. Zo worden zijn ouders onmiddellijk van zijn

Marije Jeltes is jurist en jeugdcriminoloog en als docent en onderzoeker werkzaam bij de afdeling Jeugdrecht van de faculteit der Rechtsgeleerdheid van de Universiteit Leiden. Zij is tevens (kinder)rechter-plaatsvervanger bij de rechtbank Amsterdam en rechtbank Rotterdam en lid van de afdeling Advisering van de Raad voor Strafrechtstoepassing en Jeugdbescherming (RSJ) aanhouding op de hoogte gesteld (art. 488aa lid 1 onder a Sv), een recht dat is verworven door de implementatie van Richtlijn (EU) 2016/800 ${ }^{1}$ en voorheen slechts als opdracht aan medewerkers van de politie was vastgelegd in de Ambtsinstructie. ${ }^{2}$ Deze EU-richtlijn heeft met ingang van 1 juni 2019 tot een antal belangrijke wijzigingen in de rechtspositie van de aangehouden minderjarige verdachte geleid. Deze bijdrage richt zich niet alleen op deze wijzigingen en de totstandkoming daarvan, maar ook overige wetgeving die betrekking heeft op de rechtspositie van de minderjarige tijdens de eerste fase van het strafrechtelijk onderzoek, waarbij ingrijpende dwangmiddelen kunnen worden toegepast en de minderjarige verdachte overgeleverd is an het politieen justitieapparaat. Op die momenten is niet alleen het recht op informatie over de procedure van belang, maar ook het recht op rechtsbijstand. Daarnaast is ook van belang op welke plek een minderjarige gedurende die fase verblijft; is dat een politiecel, of dient sprake te zijn van een verblijf elders? Deze en andere onderwerpen zal ik behandelen, waarbij ook wordt bezien of de Nederlandse wetgeving en praktijk in overeenstemming zijn met het internationale kinderrechtenkader, waaronder het Internationale Verdrag inzake de Rechten van het Kind (verder: IVRK), het Europese Verdrag tot

1. Art. 4 lid 1 onder a onderdeel (i) en art. 5. Richtlijn (EU) 2016/800 van het Europees Parlement en de Raad van 11 mei 2016 betreffende procedurele waarborgen voor kinderen die verdachte of beklaagde zijn in een strafprocedure.

2. Art. 27 lid 1 Ambtsinstructie: 'Voor zover het bij of krachtens het Wetboek van Strafvordering bepaalde zich hiertegen niet verzet stelt de ambtenaar een familielid of een huisgenoot van een ingeslotene zo spoedig mogelijk op de hoogte van de insluiting. In het geval de ingeslotene minderjarig is, doet hij dit uit eigen beweging, indien de ingeslotene meerderjarig is, doet hij dit slechts op verzoek van de ingeslotene.' 
bescherming van de Rechten van de Mens en fundamentele vrijheden (verder: EVRM) en de EU-Richtlijn 2016/800.

\subsection{Dwangmiddelen jegens minderjarige verdachten}

Artikel 488 lid $1 \mathrm{~Sv}$ bepaalt dat de bepalingen van dit wetboek $(\mathrm{Sv})$ van toepassing zijn, voor zover de afdeling die betrekking heeft op strafvordering in zaken betreffende personen die de leeftijd van achttien jaren nog niet hebben bereikt (art. 488 e.v. Sv) geen afwijkende bepalingen bevat. $\mathrm{Nu}$ wat de dwangmiddelen betreft geen afwijkende bepalingen zijn geformuleerd, brengt artikel 488 lid $1 \mathrm{~Sv}$ met zich mee dat alle dwangmiddelen van artikel 52 e.v. Sv van toepassing zijn op de minderjarige verdachte. Nadat een minderjarige verdachte is aangehouden, al dan niet buiten heterdaad (art. 53 resp. art. $54 \mathrm{~Sv}$ ), kan de minderjarige verdachte na voorgeleiding aan de hulpofficier van justitie worden opgehouden voor onderzoek (art. 56a lid $1 \mathrm{~Sv}$ ). Indien de minderjarige wordt verdacht van een misdrijf waarvoor voorlopige hechtenis is toegelaten, kan hij maximaal negen uur worden opgehouden voor onderzoek. De tijd tussen middernacht en negen uur 's ochtends telt hierbij niet mee (art. 56a lid $2 \mathrm{~Sv}$ ).

De minderjarige aangehouden verdachte kan worden onderworpen aan onderzoek aan het lichaam (art. 56 $\mathrm{Sv})^{3}$ of kleding (art. 55b Sv) en indien sprake is van een verdenking vanwege een voorlopigehechtenis-feit, kunnen van hem foto's en vingerafdrukken worden genomen (art. 55c lid $2 \mathrm{~Sv}$ ). Daarnaast kan in bepaalde gevallen worden binnengetreden (art. $55 \mathrm{~Sv}$ ), kan elke plaats worden doorzocht (art. 55a Sv) en speeksel of een ademtest worden afgenomen (art. $55 \mathrm{~d} \mathrm{~Sv}$ ).

Voor verdachten onder de 12 jaar geldt overigens dat eveneens dwangmiddelen kunnen worden toegepast, zoals aanhouden, ophouden voor onderzoek, bijvoorbeeld aan lichaam en kleding. In artikel 487 lid $1 \mathrm{~Sv}$ worden de artikelen uit het Wetboek van Strafvordering die op deze groep jonge verdachten van toepassing zijn, uitdrukkelijk genoemd. Zo is het nemen van foto's en vingerafdrukken voor deze verdachten uitgesloten. Voor de groep verdachten onder de 12 jaar geldt ook een afwijkende regeling met betrekking tot het ophouden voor onderzoek; dit kan voor misdrijven waarvoor voorlopige hechtenis is toegelaten niet negen uur duren, zoals bij verdachten van 12 jaar en ouder het geval is, maar maximaal zes uur (art. 487 lid $2 \mathrm{~Sv}$ ). Een verdachte onder de 12 jaar kan echter niet in verzekering worden gesteld (art. 487 lid 1 jo. art. 57 Sv). Een ander belangrijk onderscheid tussen verdachten onder en boven de 12 jaar is, dat voor de eerste groep het pressieverbod en de cautieplicht zoals neergelegd in artikel $29 \mathrm{~Sv}$, niet van toepassing zijn, nu artikel 487 lid 1 Sv deze artikelen niet uitdrukkelijk van toepassing verklaart op

3. Art. $56 \mathrm{~Sv}$ : 'het uitwendig schouwen van de openingen en holten van het onderlichaam, röntgenonderzoek, echografie en het inwendig manueel onderzoek van de openingen en holten van het lichaam.' verdachten onder de 12 jaar. Een aantal belangrijke processuele waarborgen voor verdachten is derhalve voor deze groep minderjarigen uitgesloten. Gelet op artikel 40 lid 2 onder b onderdeel (iv), dat bepaalt dat geen enkel kind dat wordt verdacht van of wordt vervolgd wegens het begaan van een strafbaar feit de garantie heeft dat het er niet toe wordt gedwongen een getuigenis af te leggen of schuld te bekennen, is het niet van toepassing verklaren van het pressieverbod op verdachten onder de 12 jaar, in strijd met het IVRK.

\subsection{Het recht op informatie (art. 488aa Sv)}

'De EU Richtlijn heeft ten doel procedurele waarborgen vast te stellen om te verzekeren dat kinderen, zijnde personen die jonger zijn dan 18 jaar, die verdachte of beklaagde zijn in een strafprocedure, deze procedure kunnen begrijpen en volgen en hun recht op een eerlijk proces uit kunnen oefenen, alsook om recidive bij kinderen te voorkomen en om hun sociale integratie te bevorderen', aldus paragraaf 1 van de Preambule van de Richtlijn. Deze paragraaf brengt tot uitdrukking dat het recht op informatie van groot belang is. De EURichtlijn van 11 mei 2016, diende uiterlijk 11 juni 2019 in de wetgeving van de EU-staten te worden geïmplementeerd. Nederland heeft deze deadline ternauwernood gered: per 1 juni 2019 was de EU-Richtlijn geïmplementeerd in het Wetboek van Strafvordering. ${ }^{4}$ Als gevolg van de implementatie van de Richtlijn is sinds 1 juni 2019 het recht op informatie over de procedure gewaarborgd (art. 488aa Sv). Het recht op informatie over de beschuldiging is reeds vastgelegd in artikel $27 \mathrm{c}$ $\mathrm{Sr}^{5}$ en vloeit eveneens voort uit artikel 40 lid 2 onder b onderdeel (ii) IVRK. ${ }^{6}$ Artikel 488 aa bepaalt dat niet alleen de ouders of voogd in kennis worden gesteld van zijn vrijheidsbeneming (art. 488aa lid 1 onder a Sv), maar ook dat aan de minderjarige aangehouden verdachte mededeling wordt gedaan van het recht tijdens het verhoor vergezeld te worden door de ouders of voogd of een vertrouwenspersoon (art. 488 lid 1 onder b Sv), van de mogelijkheid van audiovisuele registratie van verhoren (art. 488aa lid 1 onder c Sv), van het recht op een medisch onderzoek (lid 1 onder d) en van het recht op een advies over zijn persoonlijkheid en zijn levensomstandigheden (lid 1 onder e). Deze rechten zal ik uiteenzetten en toelichten.

4. Wet van 15 mei 2019 tot wijziging van het Wetboek van Strafvordering en de Overleveringswet ter implementatie van richtlijn nr. 2016/800/EU van het Europees Parlement en de Raad van 11 mei 2016 betreffende procedurele waarborgen voor kinderen die verdachte of beklaagde zijn in een strafprocedure (PbEU L 132), Stb. 2019, 180. Inwerkingtreding 1 juni 2019, Stb. 2019, 181.

5. Art. 27c Sr: 'Aan de verdachte wordt bij zijn staandehouding of aanhouding medegedeeld ter zake van welk strafbaar feit hij als verdachte is aangemerkt. Buiten gevallen van staandehouding of aanhouding wordt de verdachte deze mededeling uiterlijk voorafgaand aan het eerste verhoor gedaan.'

6. Art. 40 lid 1 onder b onderdeel (ii) IVRK bepaalt dat de staten die partij zijn bij het verdrag waarborgen dat ieder kind dat wordt verdacht van of vervolgd wegens het begaan van een strafbaar feit, tenminste de volgende garanties heeft: (ii) dat het onverwijld en rechtstreeks in kennis wordt gesteld van de tegen hem of haar ingebrachte beschuldigingen, indien van toepassing door tussenkomst van zijn of haar ouders of wettige voogd. 


\subsection{Het recht op bijstand door ouder(s), voogd of} een vertrouwenspersoon (art. 488ab Sv)

Artikel 488ab Sv bepaalt in lid 1 dat de verdachte bij het verhoor door de opsporingsambtenaar het recht heeft te worden vergezeld door de ouders of voogd of een vertrouwenspersoon. Volgens lid 2 kan de toegang van de persoon tot het verhoor worden geweigerd, indien de hulpofficier van justitie van oordeel is dat (a) het niet in het belang van de verdachte is dat hij door de ouder of voogd of vertrouwenspersoon wordt vergezeld, of (b) het belang van het onderzoek zich tegen die anwezigheid verzet. De MvT geeft geen voorbeelden van situaties waarin sprake kan zijn van een weigeringsrond, maar denkbaar is dat de anwezigheid van een ouder geweigerd wordt op moment dat de ouder eveneens als verdachte is bestempeld. De MvT vermeldt wel dat het inroepen van een weigeringsgrond een beperking inhoudt van het recht van de (minderjarige) verdachte op de bijstand en ondersteuning van de ouder. 'Voor de vraag of deze inbreuk gerechtvaardigd is, mag een beoordeling op enige afstand worden verlangd. De noodzaak deze beoordeling op enige afstand te laten plaatsvinden, mag er evenwel niet toe leiden dat het verhoor te lang zou moeten worden uitgesteld. Om die reden is ervoor gekozen de hulpofficier van justitie aan te wijzen als de autoriteit die over de weigeringsgronden te oordeelt. ${ }^{7}$ De hulpofficier beslist derhalve of een belangriijk recht van de minderjarige aangehouden verdachte wordt geschonden.

\subsection{Recht op audiovisuele registratie (art. 488ac} $\mathrm{Sv})$

Een ander belangrijk recht is het recht op audiovisuele registratie van het verhoor, wanneer de ernst van het misdrijf of de persoonlijkheid van de verdachte daartoe aanleiding geeft (art. 488ac Sv). Tot 1 juni 2019 bevatte het Wetboek van Strafvordering geen regeling voor audiovisuele registratie van verhoren. De 'Aanwijzing auditief en audiovisueel registreren van verhoren van aangevers, getuigen en verdachten' ${ }^{8}$ was tot de implementatie van de EU-Richtlijn het enige document, waarin de werkwijze met betrekking tot de registratie van de verhoren was vastgelegd. De MvT bij het wetsvoorstel tot implementatie van de EU-Richtlijn refereert aan deze Aanwijzing en licht het doel van deze Aanwijzing toe: 'Deze aanwijzing van het openbaar ministerie uniformeert de registratie van verhoren en stelt in enkele bijzondere gevallen de auditieve of audiovisuele registratie verplicht. De Aanwijzing is opgesteld vanuit het belang van de waarheidsvinding. Daarbij voorkomt de in deze Aanwijzing beschreven werkwijze dat er ontoelaatbare druk op de verdachte wordt uitgeoefend. ${ }^{9}$ Sinds 1 november 2018 is een nieuwe Aanwijzing auditief en audiovisueel registreren van verhoren van aangevers, getuigen en verdachten in werking getreden. ${ }^{10}$ Deze nieuwe Aanwijzing houdt in dat voor minderjarige

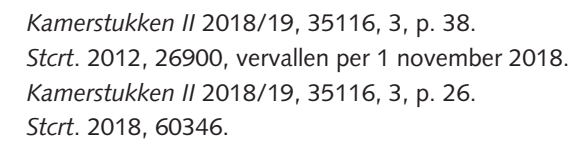

verdachten geldt, dat audiovisuele registratie verplicht is bij alle verhoren van verdachten en geplande verhoren van getuigen, slachtoffers en aangevers, wanneer de verhoorder tijdens de uitvoering van het verhoor wordt ondersteund door een gedragsdeskundige of de persoon die wordt verhoord kwetsbaar is én er sprake is van een misdrijf waarbij een overleden slachtoffer is, de strafbedreiging twaalf jaar of meer bedraagt, de strafbedreiging minder dan twaalf jaar bedraagt en er sprake is van evident zwaar lichamelijk letsel, of het gaat om een zedendelict met een strafbedreiging van acht jaar of meer of om seksueel misbruik in een afhankelijkheidsrelatie. De Aanwijzing bepaalt vervolgens dat minderjarigen onder de 16 jaar kwetsbaar zijn en dat ook personen met een (kennelijke) verstandelijke beperking of cognitieve functiestoornis kwetsbaar zijn. Indien de minderjarige onder de 12 jaar is, wordt het verhoor in een kindvriendelijke studio afgenomen. Het ingevoerde artikel 488ac Sv geeft zo bezien een aanvulling op de verplichte audiovisuele registratie zoals opgenomen in de Aanwijzing, nu de ernst van het misdrijf óf de persoonlijkheid van de verdachte de grondslag vormt voor audiovisuele registratie, hetgeen een breder toepassingsgebied met zich mee kan brengen. Het belang van deze audiovisuele registratie is met name gelegen in het recht op een eerlijk proces, zoals neergelegd in artikel 6 EVRM en artikel 40 lid 3 IVRK. De MvT spreekt over gevaar voor ongeoorloofde druk op de minderjarige en doelt daarmee op het pressieverbod dat is neergelegd in artikel $29 \mathrm{~Sv}$ en artikel 40 lid 2 onder b onder (iv) IVRK. MvT: 'De beperkte ernst van een feit kan, ook op grond van de richtlijn, aanleiding vormen van het verhoor geen opnamen te maken. Het risico op een onheuse bejegening en de kans dat zich een situatie voordoet waarin de opsporingsambtenaar ongeoorloofde druk op het kind zou uitoefenen, zijn groter wanneer de ernst van het feit waarvan de jeugdige wordt verdacht, toeneemt. Bij minder ernstige feiten ligt het minder voor de hand om aan te nemen dat ontoelaatbare druk op de verdachte zal worden uitgeoefend. ${ }^{11}$ Desalniettemin is het feit dat dit recht is opgenomen in het Wetboek van Strafvordering in plaats van in een Aanwijzing een verrijking van de rechtspositie van de minderjarige verdachte.

\subsection{Recht op medisch onderzoek (art. 489a Sv)}

Recht op medisch onderzoek vindt plaats op verzoek van de verdachte, de raadsman, de ouder of voogd of vertrouwenspersoon (art. 489a lid $1 \mathrm{~Sv}$ ), en geschiedt door een arts of onder verantwoordelijkheid van een arts (art. 489a lid $2 \mathrm{~Sv}$ ). De hulpofficier van justitie kan een dergelijk onderzoek bevelen om vast te stellen of de minderjarige aangehouden verdachte in staat is een verhoor te ondergaan of te worden onderworpen aan een onderzoekshandeling. Bij een medisch onderzoek wordt de algemene geestelijke en lichamelijke gesteldheid van de verdachte beoordeeld. Het onderzoek is zo non-invasief mogelijk (art. 489 lid $1 \mathrm{~Sv}$ ). De Raad voor Strafrechtstoepassing en Jeugdbescherming (verder: RSJ)

11. Kamerstukken // 2018/19, 35116, 3, p. 27. 
heeft in zijn advies met betrekking tot het wetsvoorstel tot implementatie van EU-Richtlijn 2016/800 de Minister van Rechtsbescherming geadviseerd een beroepsmogelijkheid voor de minderjarige te creëren bij de officier van justitie, nu het recht op een dergelijk onderzoek 'niet te gemakkelijk terzijde mag worden geschoven.' Dit advies is niet overgenomen door de Minister en heeft niet tot wijziging van het artikel geleid. De RSJ heeft daarnaast opgemerkt dat in de richtlijn aan het recht op medisch onderzoek geen beperking wordt toegekend met betrekking tot in welke fase van het strafproces het onderzoek zou kunnen worden uitgevoerd (art. 8 EU-Richtlijn) en constateert dat in het conceptwetsvoorstel dit recht wordt beperkt tot de fase van de voorgeleiding aan de hulpofficier van justitie (art. 489a $\mathrm{Sv})$. De RSJ adviseerde om deze beperking uit het conceptwetsvoorstel te schrappen en de EU-Richtlijn te volgen. ${ }^{13}$ Ook dit advies heeft niet geleid tot wijziging van het voorstel, hoewel evident is dat de EU-Richtlijn een breder toepassingsbereik van het medisch onderzoek bedoelde, nu artikel 8 lid 2 EU-Richtlijn bepaalt: 'De uitkomst van het medisch onderzoek weegt mee als moet worden vastgesteld in hoeverre het betrokken kind in staat is om een verhoor of een andere onderzoekshandeling of procedure voor het vergaren van bemijsmateriaal te ondergaan, dan wel enige andere maatregel die met betrekking tot het kind is genomen of gepland.' (cursivering; Mf). Dit gaat verder dan hetgeen is bepaald in artikel 489a Sv. De MvT licht het verzet tegen bredere toepassing van het recht op onderzoek toe door te stellen dat de lichamelijke integriteit en de persoonlijke levenssfeer van de verdachte in het geding zijn en dat dit om terughoudendheid vraagt. ${ }^{14}$ De vraag is of dit standpunt te verdedigen is als de minderjarige verdachte, al dan niet via zijn raadsman, zelf om dit onderzoek vraagt.

\subsection{Recht op rechtsbijstand}

De minderjarige aangehouden verdachte heeft recht op consultatiebijstand gedurende een termijn van hoogstens een halfuur, voorafgaand aan het eerste verhoor. De hulpofficier van justitie kan deze termijn, indien deze ontoereikend blijkt, op verzoek van de verdachte of zijn raadsman met ten hoogste een halfuur verlengen, tenzij het belang van het onderzoek zich daartegen verzet (art. 28c Sv). Van dit recht kan sinds 1 maart 2017 geen afstand meer worden gedaan, nu artikel 489 lid 2 Sv het artikel waarin sprake is van vrijwillig en ondubbelzinnig afstand doen van dit recht (art. 28a Sv) voor minderjarigen niet van toepassing verklaart. De minderjarige heeft ook recht op rechtsbijstand tijdens het verhoor, een recht waarvan sinds 1 juni 2019 op grond artikel 489 lid $2 \mathrm{~Sv}$ evenmin afstand kan worden gedaan. Deze bepalingen vinden hun oorsprong in jurisprudentie van het Europese Hof voor de Rechten van de Mens

12. Afdeling Advisering van de Raad voor Strafrechtstoepassing en Jeugdbescherming, advies 'EU Richtlijn Jeugd' d.d. 31 januari 2018, p. 5.

13. Afdeling Advisering van de Raad voor Strafrechtstoepassing en Jeugdbescherming, advies 'EU Richtlijn Jeugd' d.d. 31 januari 2018, p. 5.

14. Kamerstukken I/ 2018/19, 35116, 3, p. 24. (verder: EHRM), waarbij ook het IVRK een belangrijke rol heeft gespeeld.

\subsubsection{Salduz en Panovits-arresten}

Sinds de arresten Salduz t. Turkije ${ }^{15}$ en Panovits t. Cyprus $^{16}$ eind 2008, en een drietal daaropvolgende arresten van de Hoge Raad van 30 juni $2009,{ }^{17}$ is de rechtspositie van aangehouden minderjarige verdachten drastisch verbeterd. Salduz en Panovits waren minderjarige aangehouden verdachten die hadden geklaagd over schending van artikel 6 EVRM (recht op een eerlijk proces), aangezien zij tijdens de fase van het politieverhoor geen rechtsbijstand hadden genoten. In beide gevallen concludeerde het EHRM dat sprake was van schending van artikel 6 EVRM: het recht op een eerlijk proces was geschonden, vanwege het gebrek aan rechtsbijstand in de eerste fase van het politieverhoor. ${ }^{18}$ In de motivering van de beslissing inzake Salduz refereert het EHRM aan het IVRK en aan het General Comment Nr. 10 (2007), ${ }^{19}$ dat inmiddels vervangen is door General Comment Nr. 24 (2019). ${ }^{20}$ Een General Comment betreft een commentaar door het VN-Kinderrechtencomité op een of meerdere verdragsbepalingen in het IVRK. Deze commentaren zijn niet bindend, maar wel gezaghebbend. Het EHRM meent dat artikel 6 EVRM normaal gesproken met zich mee brengt, dat de verdachte gedurende het stadium van het politieverhoor rechtsbijstand krijgt. ${ }^{21}$ Deze principes komen overeen met internationale mensenrechtenstandaarden, ${ }^{22}$ waaronder artikel 37 onder d IVRK wordt begrepen, ${ }^{23}$ dat bepaalt dat 'staten die partij zijn bij dit verdrag waarborgen dat ieder kind dat van zijn of haar vrijheid is beroofd het recht heeft onverwijld te beschikken over juridische en andere passende bijstand, alsmede het recht de wettigheid van zijn vrijheidsberoving te betwisten ten overstaan van een rechter of een andere bevoegde, onafhankelijke en onpartijdige autoriteit, en op een onverwijlde beslissing ten aanzien van dat beroep.' Ook wordt General Comment Nr. 10 van het VN-Kinderrechtencomité genoemd als internationale standaard. ${ }^{24}$ Daarin benadrukt het VN-Kinderrechtencomité het belang van het recht op rechtsbijstand voor minderjarige verdachten en stelt dat dit recht ook bestaat tijdens het politieverhoor. ${ }^{25}$ Mede op grond van deze internationale mensenrechtenstandaarden, in dit geval het IVRK en

15. EHRM 27 november 2008, ECLI:CE:ECHR:2008:1127JUD003639102 (Salduz t. Turkije), par. 12-17

16. EHRM 11 december 2008, ECLI:CE:ECHR:2008:1211JUD000426804 (Panovits t. Cyprus), via.

17. HR 30 juni 2009, ECLI:NL:HR:2009:BH3079, NJ 2009/349, ECLI:NL:HR:2009:BH3081, NJ 2009/350 en ECLI:NL:HR:2009:BH3084, NJ 2009/351

18. Panovits t. Cyprus, par. 77, resp. Salduz t. Turkije, par. 55.

19. General Comment Nr. 10 (2007) on children's rights in juvenile justice d.d. 25 april 2007, CRC/C/GC/10.

20. General Comment Nr. 24 (2019) on children's rights in the child justice system d.d. 18 september 2019, CRC/C/GC/24

21. Salduz t. Turkije, par. 52.

22. Salduz t. Turkije, par. 53.

23. Salduz t. Turkije, par. 34

24. Salduz t. Turkey, par. 35

25. Zie par. 49 en 52 General Comment Nr. 10. Inmiddels in deze General Comment vervangen door CRC/C/GC 24, par. 49-53. Via https:// 
General Comment Nr. 10, concludeert het EHRM tot schending van artikel 6 EVRM.

\subsubsection{Arresten van de Hoge Raad}

De Hoge Raad bepaalde vervolgens dat 'een verdachte die door de politie is aangehouden, aan art. $6 \mathrm{EVRM}$ een aanspraak op rechtsbijstand kan ontlenen die inhoudt dat hem de gelegenheid wordt geboden om voorafgaand aan het verhoor door de politie aangaande zijn betrokkenheid bij een strafbaar feit een advocaat te raadplegen. ${ }^{26}$ De Hoge Raad gaat met betrekking tot minderjarige aangehouden verdachten echter een stap verder, door in deze arresten te bepalen 'dat voor aangehouden jeugdige verdachten geldt dat zij tevens recht hebben op bijstand door een raadsman of een andere vertrouwenspersoon tijdens het verhoor door de politie. ${ }^{27} \mathrm{Na}$ een aantal uitspraken over het al dan niet uitdrukkelijk afstand doen van rechtsbijstand, wees de Hoge Raad eind 2015 arrest met de strekking dat alle aangehouden verdachten, zowel minder- als meerderjarig, per 1 maart 2016 recht hebben op bijstand door een advocaat tijdens het verhoor, tenzij dwingende redenen bestaan om dat recht te beperken. De Hoge Raad bepaalde ook dat het recht op rechtsbijstand niet alleen betrekking heeft op het eerste verhoor, maar ook op daaropvolgende verhoren. ${ }^{28}$ Sinds 1 maart 2017 bevat het Wetboek van Strafvordering specifieke bepalingen over consultatie- en verhoorbijstand aan aangehouden verdachten, of deze nu minderjarig of volwassen zijn. ${ }^{29}$ Per 1 juni 2019 kan de minderjarige geen afstand meer doen van verhoorbijstand.

\subsubsection{Niet aangehouden minderjarige verdachten en verdachten onder de 12 jaar}

De Nederlandse wetgeving met betrekking tot de verhoorbijstand aan minderjarige aangehouden verdachten lijkt in overeenstemming te zijn met de EU-Richtlijn en het IVRK. Dit geldt echter niet voor minderjarige verdachten die niet zijn aangehouden. $\mathrm{Nu}$ het IVRK geen onderscheid maakt tussen aangehouden en nietaangehouden verdachten, is de vraag of het recht op rechtsbijstand zoals neergelegd in artikel 40 lid 2 onder b onderdeel (ii), dat bepaalt dat ieder kind dat verdacht wordt van of vervolgd wordt vanwege een strafbaar feit de garantie krijgt dat het juridische of andere passende bijstand krijgt in de voorbereiding en het voeren van zijn of haar verdediging, niet geschonden wordt. Dit geldt evenzeer voor minderjarige verdachten onder de 12 jaar. Hoewel zij niet vervolgd kunnen worden (art. $486 \mathrm{~Sv}$ ), kunnen dwangmiddelen worden ingezet, zoals het aanhouden en het ophouden voor onderzoek (art.

tbinternet.ohchr.org/_layouts/15/treatybodyexternal/Download.aspx? symbolno=CRC/C/GC/24\&Lang=en.

26. HR 30 juni 2009, ECLI:NL:HR:2009:BH3079, r.o. 2.5

27. HR 30 juni 2009, ECLI:NL:HR:2009:BH3079, r.o. 2.6

28. HR 22 december 2015, ECLI:NL:HR:2015:3608, r.o. 6.3

29. Wet van 17 november 2016, houdende wijziging van het Wetboek van Strafvordering en enige andere wetten in verband met aanvulling van bepalingen over de verdachte, de raadsman en enkele dwangmiddelen d.d. 17 november 2017 (Stb. 2017, 476). In werking getreden op 1 maart 2017, (Stb. 2017, 66)
487 lid 1 jo. art. 53/54 resp. art. 56a Sv). Naar de omvang van criminaliteit door kinderen onder de 12 is weinig onderzoek gedaan. Uit zelfrapportages over 2015 blijkt dat $20 \%$ van de 10 - en 11-jarigen zegt in de afgelopen 12 maanden een delict te hebben gepleegd. ${ }^{30}$ Onderzoek naar de geregistreerde criminaliteit laat een ander beeld zien. In 1996 is onderzoek gedaan naar het aantal verhoorde kinderen tussen de 7 en 12 jaar in Amsterdam, Haarlem en Alphen aan den Rijn in de jaren 1994 en 1995. ${ }^{31}$ In Amsterdam werden in 1995199 jongeren verhoord, dat is $0,6 \%$ van de totale populatie in die leeftijdscategorie. De onderzoekers concluderen dan ook dat het wel meevalt met de aantallen geregistreerde strafbare feiten die door 12-minners gepleegd worden. ${ }^{32}$ Onderzoek uit 2008 bevestigt dit beeld: minder dan $1 \%$ van alle kinderen tot 12 jaar wordt geregistreerd als verdachte van een strafbaar feit. ${ }^{33}$ Het betreft hier echter nog wel enkele duizenden kinderen. ${ }^{34}$ Onduidelijk is welk deel van deze kinderen ook is aangehouden, maar dat kinderen onder de 12 jaar worden aangehouden, is een feit. ${ }^{35} \mathrm{Er}$ zijn wel cijfers over het aantal gevallen van ophouden voor onderzoek voor 12 minners: in 2016 waren dat er 157, in 2013130 en in $201877 .{ }^{36} \mathrm{Nu}$ artikel $487 \mathrm{~Sv}$, artikel $28 \mathrm{~Sv}$ niet van toepassing verklaart, heeft de 12-minner die is aangehouden en wordt opgehouden voor onderzoek, geen recht op rechtsbijstand. Dit is in strijd met voornoemd artikel 40 lid 2 onder b onderdeel (ii) IVRK en artikel 37 onder d IVRK, dat bepaalt dat staten waarborgen dat ieder kind dat van zijn of haar vrijheid is beroofd, het recht heeft onverwijld te beschikken over juridische en andere passende bijstand. Hierbij wordt geen onderscheid gemaakt tussen kinderen die al dan niet strafrechtelijk aansprakelijk zijn. Nederland schendt hiermee de verdragsverplichtingen volgend uit artikel 37 onder $d$ en artikel 40 lid 2 onder b onderdeel (ii) IVRK. Gezien de beperkte aantallen 12-minners die worden opgehouden

30. A.M. van der Laan \& H. Goudriaan, Monitor Jeugdcriminaliteit. Ontwikkelingen in de jeugdcriminaliteit 2007-2015, Den Haag: WODC 2016, p. 113

31. M. Grapendaal, P. van der Veer \& A. Essers, Over criminaliteit en kattenkwaad bij 7- t/m 11-jarigen, Den Haag: WODC 1996.

32. M. Grapendaal, P. van der veer \& A. Essers, Over criminaliteit en kattenkwaad bij 7- t/m 11-jarigen, Den Haag: WODC 1996, p. 9.

33. P.H. van der Laan, L. van Domburgh \& M. Hoeve, 'Child delinquency as seen by children, the police and the justice system', in: J.G. Loeber, W. Slot, P.H. van der Laan \& M. Hoeve (eds), Tomorrow's criminals: The development of child delinquency and effective interventions, Farnham: Ashgate Publishing Limited 2008.

34. L. van Domburgh, Very young offenders: Characteristics of children and their environment in relation to (re)offending, Amsterdam: Vrije Universiteit 2009, p. 11.

35. Zie o.a. '11-jarige verdachte dreigmails aangehouden': www.nhnieuws.nl/nieuws/55840/, '11-, 12- en 13-jarige aangehouden om molotovcocktail': www.telegraaf.nl/nieuws/414811084/jongensvan-11-12-en-13-aangehouden-om-molotovcocktail, 'Negentien jongeren aangehouden in Den Haag, jongste is elf jaar': www.omroepwest.nl/nieuws/3973548/Negentien-jongerenaangehouden-in-Den-Haag-jongste-is-elf-jaar en 'Jongen opgepakt met flinke messen op zak in Amsterdam': www.gids.tv/video/158091/ jongen-11-met-flinke-messen-op-zak-opgepakt-in-amsterdam.

36. Afdeling Advisering van de Raad voor Strafrechtstoepassing en Jeugdbescherming, advies 'Minderjarigen in een politiecel' d.d. 28 januari 2020, p. 36. 
voor onderzoek, is het geen veeleisende operatie om deze minderjarige verdachten van rechtsbijstand te voorzien.

\section{Vrijheidsbeneming in de eerste fase van het strafrechtelijk onderzoek}

'Kinderen wier vrijheid is ontnomen, verkeren in een bijzonder kwetsbare positie. Er dient uitdrukkelijk naar te worden gestreefd om vrijheidsbeneming bij kinderen, en met name detentie, in enig stadium voordat een rechtbank definitief heeft vastgesteld dat het betrokken kind het strafbare feit heeft gepleegd, te voorkomen, gelet op de mogelijke risico's voor hun lichamelijke, mentale en sociale ontwikkeling, en omdat vrijheidsbeneming tot moeilijkheden zou kunnen leiden ten aanzien van hun herintegratie in de samenleving., ${ }^{37}$ Deze paragraaf in de tekst van EU-Richtlijn 2016/800 betreffende de procedurele waarborgen voor kinderen die verdachte of beklaagde zijn in een strafprocedure, vat het kinderrechtenkader goed samen in een enkele zin. Zo bepaalt artikel 37 onder b IVRK dat de aanhouding, inhechtenisneming of gevangenneming van een kind overeenkomstig de wet geschiedt en slechts wordt gehanteerd als uiterste maatregel, en voor de kortst mogelijke passende duur. Artikel 37 onder c IVRK draagt staten op te waarborgen dat ieder kind dat van zijn of haar vrijheid is beroofd, wordt behandeld met menselijkheid en met eerbied voor de waardigheid inherent aan de menselijke persoon, en zodanig dat rekening wordt gehouden met de behoeften van een persoon van zijn of haar leeftijd. De vraag is hoe de Nederlandse wetgeving zich verhoudt tot de principes, zoals die zijn weergegeven in de EU-Richtlijn en in het IVRK. Zoals reeds uiteengezet, kan volgens de Nederlandse wetgeving een minderjarige verdachte van 12 jaar en ouder negen uur worden opgehouden voor onderzoek, waarbij de negen nachtelijke uren niet meetellen. In totaal kan een kind dus achttien uur van zijn vrijheid worden beroofd, alvorens een beslissing wordt genomen over het heenzenden van de verdachte, dan wel de verdachte in het belang van het onderzoek in verzekering te stellen (art. $57 \mathrm{~Sv}$ ), indien sprake is van een voorlopigehechtenisfeit (art. 58 jo. 67 $\mathrm{Sv})$. Dit bevel is ten hoogste drie dagen van kracht en kan eventueel nog met drie dagen verlengd worden (art. 58 lid $2 \mathrm{~Sv}$ ). In theorie kan een minderjarige verdachte derhalve zes dagen en achttien uur in het belang van het onderzoek worden vastgehouden, waarna eventueel een vordering tot inbewaringstelling volgt (art. $63 \mathrm{~Sv}$ ). Waar verblijft de minderjarige verdachte gedurende deze periode? In principe is de Beginselenwet Justitiële Jeugdinrichtingen (verder: Bji) van toepassing in deze

37. Richtlijn (EU) $2016 / 800$ van het Europees Parlement en de Raad van 11 mei 2016 betreffende procedurele waarborgen voor kinderen die verdachte of beklaagde zijn in een strafprocedure, par. 45 . fase van het strafrechtelijk onderzoek. Artikel $15 \mathrm{Bjj}$ bepaalt dat de maximale duur voor verblijf in een politiecel drie dagen is voor minderjarigen van 12 tot 16 jaar en tien dagen voor minderjarigen van 16 en 17 jaar. Artikel 493 lid $3 \mathrm{~Sv}$ bepaalt echter dat tot het ondergaan van inverzekeringstelling of voorlopige hechtenis elke daartoe geschikte plaats kan worden aangewezen. De inverzekeringstelling hoeft derhalve niet in een politiecel te worden ondergaan. De inverzekeringstelling kan ook thuis, bij oma, een buurvrouw, een instelling voor gesloten jeugdhulp, ggz-instelling of een Kleinschalige Voorziening doorgebracht worden. Het VN-Kinderrechtencomité heeft in General Comment Nr. 24 tot uitdrukking willen brengen dat verblijf in een politiecel niet gewenst is: 'States should further ensure that children are not held in transportation or in police cells, except as a measure of last resort and for the shortest period of time (...).' ${ }^{38}$ Daarnaast benadrukt het $\mathrm{VN}$ Kinderrechtencomité dat: 'Every child arrested and deprived of his or her liberty should be brought before a competent authority within 24 hours to examine the legality of the deprivation of liberty or its continuation.' ${ }^{39}$ Dit betekent concreet dat het VN-Kinderrechtencomité het verblijf van kinderen in een politiecel afkeurt en staten opdraagt binnen 24 uur na de vrijheidsbeneming een toetsing van deze vrijheidsbeneming en de continuering daarvan te organiseren. Specifiek met betrekking tot Nederland heeft het VN-Kinderrechtencomité al in 2015 in zijn Concluding Observations $^{40}$ zijn zorgen uitgesproken over de 'systematic detention of children in police custody for lengthy periods of time (up to 16 days). ${ }^{41}$ Ook het Kinderrechtencollectief ${ }^{42}$ stelt in aanloop naar de volgende Concluding Observations van het $\mathrm{VN}-$ Kinderrechtencomité in 2021, dat 'kinderen nog steeds te vaak en te veel tijd in een politiecel doorbrengen waar nauwelijks rekening wordt gehouden met hun leeftijd en kwetsbaarheid. ${ }^{43}$ De vraag is dan ook hoe het VN-Kinderrechtencomité zal oordelen in zijn volgende Concluding Observations, als de situatie in Nederland niet wijzigt.

Mede naar aanleiding van General Comment Nr. 24 van het VN-Kinderrechtencomité heeft de RSJ in zijn advies 'Minderjarigen in een politiecel' van 28 januari jl. de Minister van Rechtsbescherming geadviseerd de duur van verblijf in een politiecel te bekorten, alterna-

38. General Comment Nr. 24 (2019) on children's rights in the child justice system d.d. 18 september 2019, CRC/C/GC/24, par. 85

39. General Comment Nr. 24 (2019) on children's rights in the child justice system d.d. 18 september 2019, CRC/C/GC/24, par. 90 .

40. Concluding Observations betreffen observaties door het VN-Kinderrechtencomité over de implementatie van kinderrechten door een verdragsstaat, die eens per vijf jaar worden gepubliceerd.

41. VN-Kinderrechtencomité, 'Concluding observations on the fourth periodic report of the Netherlands', 16 juli 2015, CRC/C/NLD/CO/414, par. 58.

42. Het Kinderrechtencollectief is in 1995 opgericht en bestaat uit verschillende kinderrechtenorganisaties. Dit zijn Defence for Children, de Nederlandse Jeugd Raad, Stichting Kinderpostzegels Nederland, UNICEF Nederland, Terre des Hommes en Save the Children.

43. Kinderrechtencollectief, 'Inbreng op de list of issues prior to reporting (LOIPR)' (2019), issue 25, p. 36. 
tieven voor een politiecel te gebruiken en indien dan toch sprake moet zijn van een verblijf aldaar, de cel kindvriendelijker in te richten. De RSJ heeft General Comment Nr. 24 als leidraad genomen en de termijn van vierentwintig uur voor toetsing van de vrijheidsbeneming in haar advies overgenomen. In het licht van internationale kinderrechten kan Nederland wat het verblijf in de politiecel betreft nog grote sprongen maken. Op grond van de politiesystemen is niet te achterhalen wat de gemiddelde duur van het ophouden voor onderzoek of de inverzekeringstelling is. ${ }^{44} \mathrm{Op}$ dit moment is de regeling van drie en mogelijk zes dagen inverzekeringstelling volgens het internationale kinderrechtenkader in elk geval te ruim, zeker nu de Bjj mogelijk maakt dat minderjarigen gedurende die periode in een politiecel verblijven.

\section{Conclusie}

Deze bijdrage heeft laten zien dat door de implementatie van EU-Richtlijn 2016/800 de rechtspositie van de minderjarige aangehouden verdachte in de eerste fase van het strafrechtelijk onderzoek is verbeterd, met name wat betreft de rol van de ouder(s), het recht op informatie, het recht op audiovisuele registratie en het recht op medisch onderzoek. Het recht op rechtsbijstand is met name door jurisprudentie van het EHRM, waarbij het IVRK als leidraad heeft gediend, drastisch verbeterd, nu sinds 2016 achtereenvolgens het recht op consultatiebijstand en verhoorbijstand zijn verankerd in de wet en sinds 1 maart 2017, respectievelijk 1 juni 2019, het afstand doen van deze rechten door minderjarigen niet meer mogelijk is. Het gebrek aan recht op rechtsbijstand voor niet-aangehouden minderjarige verdachten en voor minderjarige aangehouden verdachten onder de 12 jaar lijkt niet in overeenstemming met het IVRK. Daarnaast kan het (langdurige) verblijf in een politiecel van minderjarige aangehouden verdachten de internationale kinderrechtentoets niet doorstaan, constateert ook de RSJ. De conclusie luidt dan ook dat de rechtspositie van minderjarige aangehouden verdachten de afgelopen jaren is verbeterd, maar dat Nederland nog niet op zijn lauweren kan rusten.

\section{'Een bosbrand'}

'Wegens brandstichting door schuld moeten Max, Jan en Klaas voor de kinderrechter verschijnen. De anderen zijn nog niet strafbaar. Wat moet er met de jongens gebeuren? Zij zijn erg onder de indruk. Klaas huilt zonder ophouden. De broeders Kuipers bijten zich op de lippen, maar ook hun is het niet onverschillig dat zij voor de rechter moeten verschijnen. De schade die zij aangericht hebben, is aanzien-

44. Afdeling Advisering van de Raad voor Strafrechtstoepassing en Jeugdbescherming, advies 'Minderjarigen in een politiecel' d.d. 28 januari 2020, p. 37. lijk. Daarnaar gemeten zou ook de strafmaat hoog moeten zijn. Het is echter een van de eerste, zij het ook nu en dan niet toegepaste, grondregels van het kinderstrafrecht, dat bij alle maatregelen die een kinderrechter heeft te nemen, de persoonlijkheid van de dader op de voorgrond moet staan. De rechter moet derhalve bij ieder van de drie nagaan of er een echte geneigdheid tot metsovertreding of verstoring van de openbare orde aanmezig is, dan mel of het gaat om een echte kmajongensstreek van onschuldige aard - zij het met ernstige gevolgen -, om jeugdige overmoed en drang tot activiteit. Ook de ouders kunnen er niet vroeg genoeg bij zijn om dit bij allerlei kattekmaad trachten vast te stellen. Zelfs mat bij het kinderspel onschuldig lijkt, moet ernstig genomen morden. Uit inlichtingen die over de drie verdachten ingemonnen konden worden, bleek dat zij niet uit kmaadaardigheid of vernielzucht gehandeld hadden.'

Ter terechtzitting stelt de vader van een van de jongens de kinderrechter voor om de jongens een meek lang iedere dag een pak slaag te laten geven, maar de kindermetten staan dat niet toe. De houtvester miens jonge aanplant door het kampvuur van de jongens is vernietigd heeft een beter plan.

\section{'In oktober moet het afgebrande stuk opnieum} morden beplant. Dat planten is geen zmaar merk en bovendien is het gezond. Het zijn allemaal flinke jongens. Hoe denkt u erover om hen tijdens de herfstvakantie bij dit merk te laten helpen? Ik zou de jongens leiding kunnen geven en toezicht op ze houden.'

Aldus wordt besloten mant, zegt de kinderrechter:

'Het is onjuist, alle problemen en vooral het probleem van de opvoeding met gemeld te millen oplossen. Geen jeugdgevangenis, maar een opvoedende maatregel of een dmangmiddel voldoende is. Geen plaatsing in een opvoedingsinrichting, manneer toezicht of misschien reeds een berisping het doel evengoed bereikt. Geen jeugdarrest, maar een vermaning, maarschuming of het opleggen van een taak voldoende is. ${ }^{45}$ 